\title{
STUDENTS' PERCEPTION TOWARD THE PLAN OF TEFL MODULE DESIGNINFG FOR COLLEGE STUDENTS BASED ON THE TEACHER TRAINING
}

\author{
Nirwana Darwis \\ Department of English Education, Institut Agama Islam Negeri Bone, Indonesia \\ Corresponding Author Email: nirwana.darwis07@gmail.com
}

\begin{abstract}
This research was done to find out Students' Perception toward the Plan of TEFL Module Designing Based on Teacher Training. The result of this research will be put into background of the next research in developing TEFL module based on the teacher training approach. A research method applied in this research was survey research. It was held at Islamic State of Institute (IAIN) Bone, Indonesia, in academic year 2017/2018. The samples of this research were 50 English study program students who have been taught TEFL material. The research data were collected through questionnaire and interview. All the samples of this research were involved to respond the questionnaire, and there were only 10 students who involved in follow-up the interview. The results of this research revealed that the mean score of students' perception was 45.18. Based on the mean scores and interview data, it showed that the students had very high perception toward the Plan of TEFL module designing based on the teacher training.
\end{abstract}

Keywords: TEFL Module, Perception, Teacher Training

\section{INTRODUCTION}

Many teachers choose teaching as their professions because of different reasons, for example, a love of teaching, a desire to help others learn, to get great career satisfaction, to have a job that can give them flexible working conditions. Teaching is often perceived to be an easy job, however in reality teaching is not as simple as it seems. Labaree (2000) states that teaching is an enormously difficult job. Many problems are inherent in the teaching profession and teacher should work hard to overcome these problems.

Being aware of the complexity of teachers' job, teachers need to be prepared well through teacher education institutions. However, this is often not sufficient. Once teachers put their steps in schools the knowledge and skills they have obtained in college are exercised. They will also get new challenges different from what they have learnt. Many English teachers have failed in making sense of their teaching job because of the lack of interaction to real classroom teaching experience providing by teacher education program. That is way the students who take English teacher education program should be prepared to be professional English teachers.

Preparing qualified English language teachers is the task that every English teacher education program has to undertake. The institutions which provide English teacher education program should be aware of preparing qualified English teachers. The students of English education program are expected to become competent and qualified English teaching professionals. To support this aim, they cannot just absorb the theory of teaching and learning but also recognize the importance of seeing the effective connection and communication between the theories and practice of English language teaching.

Teaching English as a foreign language as one of the compulsory lectures that have to be learn by all the students of English education study program should be presented in a lecture which include the theories and practice of English language teaching. So, the students are able to develop their teaching fluency and adaptability. 
IJRETAL

International Journal of Research on English Teaching and Applied Linguistics, Vol. 1, No.2, December 2020

During few years, the teaching materials for English language teaching as a foreign language only provide the theories beyond the teaching and learning and the result is the students gain the knowledge of teaching and learning theories in mind but they have no experiences to apply any techniques or method in the classroom.

This research attempts to investigate the students' perception toward the plan of TEFL module designing based on the teacher training. So, it will be as a pre-research before designing a TEFL module (Teaching English as a Foreign Language) for the College students based on the teacher training approach. This would give the learners experience the theories they had in language classroom.

\section{Review of Related Literature}

\section{Teacher Training Materials and Activities}

Teacher training will be designed according to its own particular circumstances and needs and when using the materials the trainers need to pay attention to some principals. According to Thornbury and Watskin (2007) the principals are:

a. Practical: The training has to be very practical. This is not mean avoiding theoretical issues, but simply that input sessions should always be firmly grounded in classroom practice. This may mean starting with a discussion of classroom experiences, drawing out some basic principles and returning to classroom practice through the analysis and evaluation of classroom materials.

b. Integrated: in keeping with the above point, emphasizing the interconnectedness, not only of theory and practice, but also of the different strands of the course, should be priority. These strands include the input sessions, teaching practice (TP), classroom observation and the written assignments.

c. Experiential: axiomatic to the training course is the notion that learning is optimized if it is driven by personal experience.

d. Co-operative: the course should be prepared for classroom use (as opposed to selfstudy) and such exploits the communal and collaborative nature of the training, where trainees frequently work together in pairs or small groups in order to compare experiences, solve tasks, debate issues, evaluate materials, or design lessons.

e. Reflective: A key component of the experiential learning cycle is reflection. For example, after trainees have experienced an activity as if they were learners, they can then reflect on their experience in order to extrapolate principles that might apply when setting up the same or similar activities as teachers.

In this writing the researcher focuses on developing a module for TEFL based on the in-service teacher training approach. ELTIS (English Language Training for Islamic schools) is one example of the in-service teacher training which provided good materials and various activities for the teacher to be applied in their real teaching.

Quality teachers are unquestionably needed. However, most madrasah teachers had been educated within the Islamic education system, which had traditionally had a focus on preparing teachers to teach religious subjects. Consequently, there was a big number of mismatched teachers. Rahma and Milal (2008) find out that it was estimated that more than 50\% of private madrasah teachers were part-times of volunteers. As a result, there tended to be lack of qualified English teachers in the madrasah.

Prior to the implementation of ELTIS training, need analysis and placement testing of about 1000 MTs teachers were conducted in East Java, West Nusa Tenggara, and Bone. Based on the collected data, ELTIS designed a model to help increase the quality of the English teachinglearning in MTs. The project consist of 1) training of Teacher-Trainers (TOTT) for six months, 
IJRETAL

International Journal of Research on English Teaching and Applied Linguistics, Vol. 1, No.2, December 2020

2) Madrasah Teacher development, including English Language Upgrading (ELU) courses and Communicative English Language Teacher Training (CELTT) courses for Madrasah Teachers, 3) revitalization of EL Teacher Support Groups, 4) Strengthening of District Support Networks, 5) Resource Development including Teaching Material Development, and 6) Resource Kit / Base Development. This paper will focus on Communicative English Language Teacher Training (CELTT) courses materials.

There are 5 CELTT courses and the course materials and activities are emphasized on the principles of teaching language in a communicative way on language production. The materials are:

In CELTT 1, trainees were introduced to and invited to have a review of principles of communicative language teaching. The topics were different kinds of communicative activities, promoting more learner-centered teaching, managing classroom and building good rapport with learners, lesson planning, eliciting and questioning, warmers and fillers, effective instruction, effective observers, etiquette as observers and peer teaching of communicative tasks.

CELTT 2 focused on performing a variety of teachers' and learners' roles, responding to individual differences in learners, evaluating and adapting activities in textbooks, monitoring students, correcting errors, giving feedback, using songs as a warmer and as main activities, using poem, using computers to teach English, peer teaching (special attention on monitoring learners, correcting errors and giving feedback).

Teaching receptive skills was the focus of CELLT 3. This level concentrated on experiencing an interactive reading and listening lesson, developing reading skills, evaluating whether they teach or test listening skills, reading skills and strategies, using video to teach language, using listening and reading games in the classroom, using authentic listening and reading materials, reading genres, peer teaching on reading and listening lessons.

In CELTT 4, trainees learn more about teaching productive skills. The topics were experiencing a speaking lesson, experiencing a writing lesson, helping learners with difficulties in speaking, designing portfolio tasks, teaching pronunciation, planning effective writing lessons, correction and feedback in writing, continuous assessment, filming teachers, speaking games, writing games, peer teaching on speaking and writing lesson.

CELLT 5 focused on teaching grammar and vocabulary more interestingly. The topics included learner-centered approach to teaching grammar, discovery grammar learning activities, getting learners to use English in the classroom, communicative grammar games, grammar drills and controlled practice activities, using dictoglos, a grammar focused lesson using discovery learning techniques, pre-intermediate vocabulary lesson-planning, teaching and evaluating, presenting and practicing new vocabulary, communicative vocabulary games, peer teaching ( a grammar focus lesson using discovery techniques and vocabulary-based lesson).

In this course, the trainees are involved actively. In planning a lesson and lesson consultation, the trainees are given material and topic for teaching practice. The trainees make a lesson plan based on the topic given, preparing for adapting materials, media and the teaching techniques and consulted their lesson plan to the trainers.

Teaching practice was done to give trainees opportunity to practice the model of teaching presented in the training and some aspect of the CELTT materials such as how to give instruction, how to give feedback, how to correct errors, etc.

Feedback was done by the trainers after the trainees have taught. It is aimed at learning the comments while the process was still fresh in their mind and helping them to reflect their own teaching.

As for reflecting, Darwis (2013) explore that the trainees reflect their own teaching orally based on the trainer's questions then reflect their own teaching in written based on the form given. The trainees incorporate comments they received during feedback into their own reflection. 
IJRETAL

International Journal of Research on English Teaching and Applied Linguistics, Vol. 1, No.2, December 2020

\section{Teaching English as a Foreign Language Materials}

Ur (2007) in his book states that foreign language teaching naturally includes methodology and has further components such as lesson planning, classroom discipline, the provision of interest - topics which are relevant and important to teachers of all subjects. In fact, there is no a big difference between in-service teacher training materials and teaching English as a foreign language materials, the difference is only on the practical way of teaching English. Inservice teacher training provides some basic principles of teaching English in a practical way or classroom experience, while teaching English as a foreign language materials not.

The materials in teaching English as a foreign language in English Department of STAIN Watampone (present topics) are: 1) about the teacher and the learner, 2) teaching and learning, 3) classroom management, 4) teaching vocabulary and grammar, 4) teaching pronunciation, 5) teaching receptive skills, 6) teaching productive skills, 7) planning a lesson, and 8) correcting learners. All presented in theories.

\section{Materials and Activities Adaptation}

a. Some principle for materials and activities adaptation according to Cunningsworth (1984) are:

1) Teaching materials should be related to aims and objectives

2) It is needed to be aware of what materials is for and select teaching materials which will help equip learners to use materials effectively for their own purposes.

3) Keep learners' learning in mind

4) Consider the relationship between materials, the learning process and the learners.

Considering some principles above, the researcher put some criteria for evaluating the materials, they are:

1) To what extent do the materials fit into a 90-minutes time slot?

2) To what extent do the materials help the learners make connection with their lives and purposes?

3) To what extent do the materials engage us cognitively? (Can we learn something useful and interesting from them?)

4) To what extent do the materials engage us emotionally?

5) To what extent do the materials allow for different learning styles?

6) To what extent are the materials suitable for age of the learners?

7) To what extent are the materials culturally appropriate for Indonesian learners?

8) To what extent are the materials suitable for large classes?

9) To what extent do the materials fit into vision and mission of the English Department of STAIN Watampone?

10) To what extent do the materials help the teacher to also learn something?

These criteria are used to evaluate and adapting the materials and activities form inservice teacher training, in this case ELTIS (CELTT) teacher training.

Here some additional for adapting activities explain by ELTIS team (2007) are:

1) Modify is, make small changes to the materials and activities in the coursebooks

2) Remove is, take out an activity completely

3) Replace is, take out an activity and replace it with something different.

4) Add is, add an activity. 
IJRETAL

International Journal of Research on English Teaching and Applied Linguistics, Vol. 1, No.2, December 2020

\section{Concept of Perceptions}

Wang (2007a) Perception is a set of internal sensational cognitive processes of the brain at the subconscious cognitive function layer that detects, relates, interprets, and searches internal cognitive information in the mind.

Perception may be considered as the sixth sense of human beings since almost all cognitive life functions rely on it. Perception is also an important cognitive function at the subconscious layers that determines personality. In other words, personality is a faculty of all subconscious life functions and experience cumulated via conscious life functions. It is recognized that a crucial component of the future generation computers known as the cognitive computers is the perceptual engine that mimic the natural intelligence (Wang, 2006, 2007b). Furthermore, Pickens (2005) mentioned that the perception process follows four stages: simulation, registration, organization, and interpretation.

\section{RESEARCH METHOD}

This research attempted to describe the students' perceptions toward the Plan of TEFL Module Designing based on Teacher Training. Therefore, the survey research design is considered as the suitable research design in this research. Survey research design is typically used to describe preferences, attitude, opinion, and perception of people interest to the researcher (Latief, 2013; Ary, et al, 2007; Postlethwaite, 2005). In the cross-sectional survey data are collected by one at a time (Creswell, 2010, Trochim, 2006, Rinantatnti, 2017). Questionnaires and interview are used to get in-depth responses of the students' perceptions toward the plan of TEFL Module Designing based on teacher training.

The subjects of this research were 50 Students who has taken TEFL Subject in English study program at IAIN Bone, Indonesia, in academic year 2017/2018. They were taken through simple random sampling technique. Based on the reason that the simple random sampling technique is trusted to be representative of giving population. The writers involved the same subject in survey study to interview section. But not all the subjects in survey study are involved. Only 10 students and 5 lecturers are involved in the interview section. The interview section was done after survey study to find out in depth information about students' perception toward the Plan of TEFL Module designing based on teacher training.

\section{FINDING AND DISCUSSION}

\section{A. Results}

The students' perception toward the plan of TEFL module designing based on teacher training

This section provides the results of students' perception. The questionnaire was distributed to the students to find out their perception toward the plan of TEFL module designing based on teacher training. The results of students' perceptions can be seen in the table below: 
IJRETAL

International Journal of Research on English Teaching and Applied Linguistics, Vol. 1, No.2, December 2020

Table 1. The students' perception toward the plan of nursing English material development based on need analysis.

\begin{tabular}{|c|c|c|c|c|c|c|c|}
\hline $\begin{array}{l}\text { Questionnaire } \\
\text { Items }\end{array}$ & $\begin{array}{c}\text { Strongly } \\
\text { Disagree } \\
(\%)\end{array}$ & $\begin{array}{c}\text { Disagree } \\
(\%)\end{array}$ & $\begin{array}{l}\text { Undecid } \\
\text { ed }(\%)\end{array}$ & $\begin{array}{l}\text { Agree } \\
(\%)\end{array}$ & $\begin{array}{c}\text { Strongly } \\
\text { Disagree } \\
(\%)\end{array}$ & $\begin{array}{l}\text { Mean } \\
\text { Score }\end{array}$ & $\begin{array}{c}\text { Standard } \\
\text { Deviation }\end{array}$ \\
\hline $\begin{array}{l}\text { TEFL module } \\
\text { designing based } \\
\text { on teacher } \\
\text { training is able } \\
\text { to be used and } \\
\text { taught in } \\
\text { English study } \\
\text { program }\end{array}$ & 0 & 0 & 2 & 36 & 62 & 4.60 & 0.535 \\
\hline $\begin{array}{l}\text { TEFL module } \\
\text { based on teacher } \\
\text { training is able } \\
\text { to replace the } \\
\text { TEFL material } \\
\text { which is not } \\
\text { made based on } \\
\text { teacher training }\end{array}$ & 0 & 0 & 22 & 66 & 12 & 3.90 & 0.580 \\
\hline $\begin{array}{l}\text { Teaching TEFL } \\
\text { using module } \\
\text { based on the } \\
\text { teacher training } \\
\text { will be more } \\
\text { useful for } \\
\text { students }\end{array}$ & 0 & 0 & 0 & 36 & 64 & 4.64 & 0.485 \\
\hline $\begin{array}{l}\text { Students will be } \\
\text { motivated to } \\
\text { teaching } \\
\text { practice by } \\
\text { using TEFL } \\
\text { Module based } \\
\text { on teacher } \\
\text { training }\end{array}$ & 0 & 0 & 0 & 48 & 52 & 4.52 & 0.505 \\
\hline $\begin{array}{l}\text { Students can } \\
\text { improve their } \\
\text { teaching skills } \\
\text { by using TEFL } \\
\text { module based } \\
\text { on teacher } \\
\text { training }\end{array}$ & 0 & 0 & 0 & 40 & 60 & 4.60 & 0.495 \\
\hline $\begin{array}{l}\text { Teaching TEFL } \\
\text { by using module } \\
\text { based on teacher } \\
\text { training will } \\
\text { help students to } \\
\text { improve their } \\
\text { teaching skills } \\
\end{array}$ & 0 & 0 & 2 & 42 & 56 & 4.54 & 0.542 \\
\hline
\end{tabular}


IJRETAL

International Journal of Research on English Teaching and Applied Linguistics, Vol. 1, No.2, December 2020

\begin{tabular}{|c|c|c|c|c|c|c|c|}
\hline $\begin{array}{l}\text { Students will be } \\
\text { more active in } \\
\text { teaching } \\
\text { practice if TEFL } \\
\text { Module is based } \\
\text { on teacher } \\
\text { training }\end{array}$ & 0 & 0 & 2 & 38 & 60 & 4.58 & 0.538 \\
\hline $\begin{array}{l}\text { Students will be } \\
\text { more interested } \\
\text { in teaching } \\
\text { practice if TEFL } \\
\text { module is based } \\
\text { on teacher } \\
\text { training }\end{array}$ & 0 & 0 & 4 & 46 & 50 & 4.46 & 0.579 \\
\hline $\begin{array}{l}\text { I agree to learn } \\
\text { TEFL by using } \\
\text { module based } \\
\text { on the teacher } \\
\text { training }\end{array}$ & 0 & 0 & 0 & 40 & 60 & 4.60 & 0.495 \\
\hline $\begin{array}{l}\text { Teaching TEFL } \\
\text { based on teacher } \\
\text { training, means } \\
\text { preparing } \\
\text { students to be } \\
\text { able to teach in } \\
\text { the real } \\
\text { classroom }\end{array}$ & 0 & 0 & 0 & 26 & 74 & 4.74 & 0.443 \\
\hline
\end{tabular}

Table 1 above shows that most of the students chose agree and strongly agree to respond the questionnaire which was given to them. Only few of them chose undecided and none of them chose disagree or strongly disagree as the response to the questionnaire. Furthermore; there are 5 questions in the questionnaire given that there are some students chose undecided. The 5 questions are question number 1 (TEFL module designing based on teacher training is able to be used and taught in English study program). Question number 2 (TEFL module based on teacher training is able to replace the TEFL material which is not made based on teacher training). Question number 6 (Teaching TEFL by using module based on teacher training will help students to improve their teaching skills). Question number 7 (Students will be more active in teaching practice if TEFL Module is based on teacher training). And question number 8 (Students will be more interested in teaching practice if TEFL module is based on teacher training). The important thing to be noticed that mostly the students chose agree and strongly agree. Only few of them chose undecided and none of them chose disagree or strongly disagree.

The data of the students' perception interval score was in high and very high category. There were 46 (92\%) of the students had very high perception and $4(8 \%)$ of the students had high perception, and none of the students had moderate, low or very low perception toward the plan of TEFL module designing based on teacher training. It can be seen in the figure below: 
IJRETAL

International Journal of Research on English Teaching and Applied Linguistics, Vol. 1, No.2, December 2020

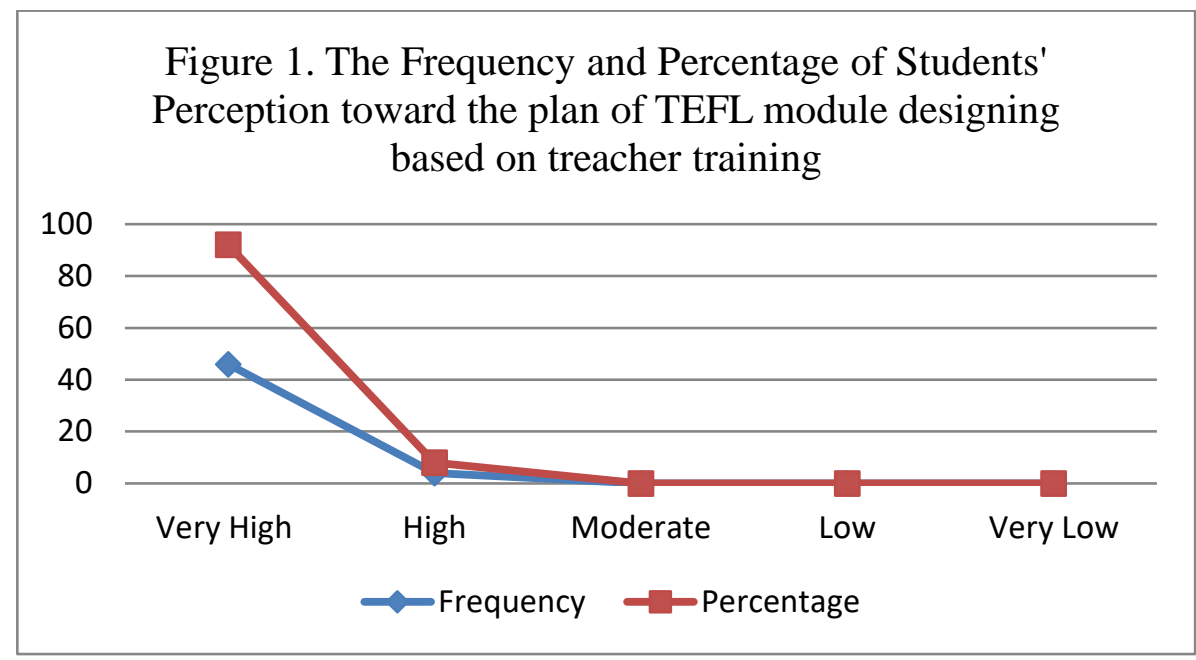

Table 2. The mean score and standard deviation of Students' perception toward the plan of TEFL Module designing based on teacher training.

\begin{tabular}{ccc}
\hline Variable & Mean Score & $\begin{array}{c}\text { Standard } \\
\text { Deviation }\end{array}$ \\
\hline $\begin{array}{c}\text { Students' } \\
\text { Perception }\end{array}$ & 45.18 & 2.988 \\
\hline
\end{tabular}

Table 2 above shows that the mean score of students' perception was 45.18 with standard deviation was 2.988. It shows that the students had very high perception toward the plan of TEFL Module designing based on teacher training.

\section{The results of Interviews}

The result of the interview shows that the students agree with the plan in designing TEFL Module based on the teacher training. The explanations of students' perception are as follows:

"From my point of view, I agree with the plan of designing TEFL module based on the teacher training. The students, who will work in real schools, will need teaching skills, and the skills can be also gotten through practicing the TEFL module which is done based on teacher training" (student a).

"In my opinion, I agree very much with the plan to teach by using TEFL module based on teacher training. Students need to experience the theory in teaching before coming to the real class and it's on the TEFL module based on the teacher training. To have an appropriate skill with what they need, they have to practice it. It means that all the material which is taught to students should be practiced and it is on the TEFL module based on teacher training" (student b).

"I agree with the plan to design TEFL module based on teacher training, because the teaching practice and experience are important for students. Moreover, for students, who will teach at school. And as a teacher, I have to have teaching skills, so I can handle my teaching well and professionally" (student c). 
IJRETAL

International Journal of Research on English Teaching and Applied Linguistics, Vol. 1, No.2, December 2020

The result of the interview also shows that students will be interested in teaching practice if the teaching TEFL is based on teacher training. The more explanations of the students about their interest to TEFL module based on teacher training are as follows:

"Yes of course, the students will be more interested in teaching practice later. We are teacher students; we will need very much teaching skills, the TEFL module will more interested to be studied if the material is based on teacher training" (student d).

"In my opinion, yes, the students will be very interested in teaching practice using TEFL module which designed based on teacher training" (student e).

Yes, the students will be more interested in teaching practice specially in TEFL class if the teaching materials used are based on teacher training" (student f).

The interview data above shows that students agree or give a positive opinion toward the plan of TEFL module designing based on teacher training. It means that the plan to design the module is supported by the students. There are many reasons why the students agree with the plan in designing TEFL module based on teacher training. The reasons of the students like what they have mentioned in the interview data above.

\section{B. Discussions}

The analysis data shows that mostly students gave positive response to the question which was given to them by choosing agree and strongly agree. Only few of them chose undecided and none of them chose disagree or strongly disagree as the response to the questionnaire. Furthermore; the mean score of the students' perception toward the plan of TEFL module designing based on teacher training was 45.18 and the standard deviation was 2.988 . It shows that students had very high perception toward the plan of nursing English material development based on need analysis.

The data of interview is consistent with the data from the questionnaire. From the data of interview, we know that students agree or give a positive response toward the plan of TEFL module designing based on teacher training.

\section{CONCLUSION}

Based on the results and discussions above, it can be concluded that the perception of students toward the plan of TEFL module based on teacher training is positive. It is proved by the mean score of students' perception was 45.18 with standard deviation was 2.988 which show that students had very high perception toward the plan of TEFL module designing based on teacher training.

\section{REFERENCES}

Ary, D., Jacobs, L. C., \& Sorensen, C. (2007). Introduction to Research Education. (8th Ed.). Belmont: Wadsworth

Arikunto Suharsimi, et. al. Penelitian Tindakan Kelas, Jakarta: PT Bumi Aksara, 2008

Creswell, J. W. (2010). Research Design Qualitative, Quantitative, and Mixed Methods. (3rd Eds.). California: Sage.

Cunningsworth, A. (1984) Evaluating and Selecting EFL Materials, Oxford: Heinemann International, 
IJRETAL

International Journal of Research on English Teaching and Applied Linguistics, Vol. 1, No.2, December 2020

Darwis Nirwana. (2013) Reflecting Teaching in In-service Teacher Training: An Experience Being an ELTIS Trainer In Watampone. Paper Presented at TESIC International Conference, Johor, Malaysia.

ELTIS Team, (2007) CELTT (Communicative English Language Teacher Training) Course. Module 1. Bali: LAPIS-ELTIS.

ELTIS Team, (2007) CELTT (Communicative English Language Teacher Training) Course. Module 2. Bali: LAPIS-ELTIS.

ELTIS Team, (2007) CELTT (Communicative English Language Teacher Training) Course. Module 3. Bali: LAPIS-ELTIS.

ELTIS Team, (2007) CELTT (Communicative English Language Teacher Training) Course. Module 4. Bali: LAPIS-ELTIS.

Labaree, DF. (2000) On the Nature of Teaching and Teacher Education: Difficult Practice that look easy, Journal of Teacher Education.

Latief, M. A. (2013). Research Methods on Language Learning an Introduction. Malang: UM Press.

Latief, Muhammad Adnan. http://silusphysic.com /2013/ 04/ 19/ptk. Retrieved on August, $7^{\text {th }}$ 2014

Pickens, J. Attitudes and Perceptions. In Borkowski, N (Eds.). (2005). Organizational Behavior in Health Care. Mississauga: Jones \& Bartlett Publishers Canada.

Postlethwaite, T. N. (2005). Educational Research: Some Basic Concepts and Terminology. Paris: International Institute for Educational Planning.

Rinantanti, Y. (2017). Perception of senior high school EFL Teachers in Papua, Indonesia towards their own competence. Jounal of Language Teaching and Research, Vol. 8, No. 6, pp. 1181-1189.

Rohmah, Z and Milal, (2008) A. ELTIS: A Response to the Needs of English teachers at Islamic Schools in Indonesia. Paper presented at Asia TEFL International Conference, Bali, Indonesia.

Scrievener, J. (1994) Learning Teaching, Oxford: Heinemann English Language Teaching,

Trochim, W. M. (2006). The Research Methods Knowledge Base. (2nd Eds.). Cincinnati: Atomic Dog Publishing.

Thornburry, S. (2006) An A-Z of ELT: A dictionary of terms and concepts used in English Language Teaching, Thailand: Macmillan Education.

Thornburry, S and Watkins, P. (2007) The CELTA (Certificate in English Language Teaching to Adults) Course, Cambridge: Cambridge University Press. 
IJRETAL

International Journal of Research on English Teaching and Applied Linguistics, Vol. 1, No.2, December 2020

Ur, P. (2007) A Course in Language Teaching (Practice and Theory), Cambridge: Cambridge University Press.

Wang, Yingxu. (2007a). On the cognitive processes of Human perception with Emotions, Motivations, and Attitudes. International Journal of Cognitive Informatics and Natural Intelligence, 1(4), 1-133, October-December 2007

Wang, Y. (2007b). Towards theoretical foundations of autonomic computing. The International Journal of Cognitive Informatics and Natural Intelligence, 1(3), 1-15 